\title{
Concordance between macroinvertebrate communities and the typological classification of white and clear-water streams in Western Brazilian Amazonia
}

\author{
Fabio de Oliveira Roque ${ }^{1,7}$, Diego Viana Melo Lima ${ }^{2}$, Tadeu Siqueira ${ }^{3}$, Lisandro Juno Soares Vieira ${ }^{4}$, \\ Maurício Stefanes ${ }^{5}$ \& Susana Trivinho-Strixino ${ }^{6}$ \\ ${ }^{1}$ Centro de Ciências Biológicas e da Saúde, Universidade Federal de Mato Grosso do Sul - UFMT, \\ Cidade Universitária, CP 549, CEP 79070-900, Campo Grande, MS, Brasil \\ ${ }^{2}$ Laboratório de Entomologia, Centro de Ciências Biológicas e da Natureza, Universidade Federal \\ do Acre - UFAC, Rod. BR 364, Km 04, 6637, Distrito Industrial, CP 500, \\ CEP 69915-900, Rio Branco, AC, Brasil \\ ${ }^{3}$ Departamento de Ecologia, Universidade Estadual Paulista - UNESP, \\ CEP 13506-900, Rio Claro, SP, Brasil \\ ${ }^{4}$ Laboratório de Ictiologia e Ecologia Aquática, Centro de Ciências Biológicas e da Natureza, \\ Universidade Federal do Acre - UFAC, Rod. BR 364, Km 04, 6637, Distrito Industrial, CP 500, CEP \\ 69915-900, Rio Branco, AC, Brasil \\ ${ }^{5}$ Faculdade de Ciências Biológicas e Ambientais, Universidade Federal da Grande Dourados - UFGD, \\ CEP 79825-070, Dourados, MS, Brasil \\ ${ }^{6}$ Laboratório de Ecologia de Insetos Aquáticos, Universidade Federal de São Carlos - UFSCar, Rod. \\ Washington Luis, Km 235, CP 676, CEP 13565-905, São Carlos, SP, Brasil \\ ${ }^{7}$ Corresponding author: Fabio de Oliveira Roque, e-mail: roque.eco@gmail.com
}

ROQUE, F.O., LIMA, D.V.M., SIQUEIRA, T., VIEIRA, L.J.S., STEFANES, M. \& TRIVINHO-STRIXINO, $S$. Concordance between macroinvertebrate communities and the typological classification of white and clear-water streams in Western Brazilian Amazonia. Biota Neotrop. 12(2): http://www.biotaneotropica.org. br/v12n2/en/abstract?article+bn01512022012

\begin{abstract}
In this study we have attempted to answer whether there is correspondence between aquatic macroinvertebrate communities and the typological classification of white and clean-water streams in western Amazonia lowlands. We worked within two distinct hydrographic basins: Moa River catchment (clear-water streams) and Azul River catchment (white-water streams) in Serra do Divisor National Park, Acre State, Brazil, sampling 10 streams in each basin. A total of 2,952 individuals were collected, distributed among 134 taxa. Our results show that macroinvertebrate communities, at genus as well as family level, are in concordance to a priori classifications that distinguish between white and clear water streams. The main implication of our results for biomonitoring is that biotic variation between white and clear streams can be partitioned regionally, which would improve the bioassessment accuracy of the Amazonian streams.
\end{abstract}

Keywords: aquatic insects, biodiversity, neotropical region, biomonitoring, Brazil.

ROQUE, F.O., LIMA, D.V.M., SIQUEIRA, T., VIEIRA, L.J.S., STEFANES, M. \& TRIVINHO-STRIXINO, S. Concordância entre comunidade de macroinvertebrados e classificação tipológica de igarapés em águas brancas e claras no oeste Amazônico, Brasil. Biota Neotrop. 12(2): http://www.biotaneotropica.org.br/v12n2/ pt/abstract?article+bn01512022012

Resumo: Neste trabalho, nós investigamos se há correspondência entre comunidade de macroinvertebrados e classificação de igarapés em águas claras e brancas no oeste da Amazônia. Nós trabalhos em duas bacias hidrográficas, Rio Moa (águas claras) e Rio Azul (águas brancas) no Parque Nacional da Serra do Divisor, Acre, Brasil, amostrando 10 igarapés em cada bacia. Coletamos 2952 indivíduos, distribuídos em 134 taxa. Nossos resultados mostram que a comunidade de macroinvertebrados, identificada com baixa e alta resolução taxonômica, responde claramente a classificação tipológica de igarapés em águas claras e brancas. A principal implicação dos nossos resultados no âmbito de biomonitoramento é que a partição da variação biótica entre igarapés de águas claras e brancas pode melhorar a racionalidade e implantação de sistemas de avaliação ambiental na Amazônia. Palavras-chaves: insetos aquáticos, biodiversidade, região neotropical, biomonitoramento, Brasil. 


\section{Introduction}

Studies on the correspondence between communities and aquatic system classifications have a long history in ecology and limnology, going back to the pioneer studies of Thienemam in the beginning of the 1900s. Recently, there has been renewed interest in typologies and classifications of aquatic ecosystems due to their implication for biomonitoring and conservation (Heino et al. 2003, Padial et al. 2012). Many classification schemes have been used to test for concordance between landscape patterns and structural and functional aspects of biological communities (e.g. Hawkins \& Norris 2000).

In the Neotropical region, particularly in Amazonia, it has been accepted that differences in river discharges, channel morphologies, flood cycles and water chemistry have reflected in the evolution and ecology of aquatic communities (Sioli 1984, Junk \& Soares 2001). Amazonian rivers and streams are classified in terms of their size, channel morphology (anastomosing, braided and meandering) and 'color' (white water, black water and clear water) (Sioli 1950, Junk $\&$ Furch 1985). While white-water rivers have muddy color due to their high sediment content, black-water rivers have dark transparent water because of the large amount of dissolved humic substances carried from the forest, and clear-water rivers drain areas where there is little erosion.

Despite the broad acceptance of this classification based on watercolor, and their hypothetical importance for evolution and ecology of Amazonian diversity, few data on macroinvertebrate distribution in black and clear-water streams in Amazonia exist. Moreover, most of the available information is from the central part of the region (Fittkau 1971, Walker 1995, Couceiro et al. 2007, Nessimian et al. 2008) and to our knowledgement there is no previous study on white-water streams.

Western Amazonian forests have been postulated to possess one of the most diverse and endemic faunal and floral biota on Amazonia (Gentry 1988, Wilson \& Sandoval 1996, S.O.S. Amazônia 1998). The western part of the Amazon basin is a region characterized by abundant dynamic headwaters of the Amazonas River, being influenced by tectonic activities of the Andean foothills and foreland (Räsänen et al. 1987). Streams of this region provide a good system for exploring and testing possible association between different types of streams and biological communities. Besides the fact that the area encompasses high biological diversity and variable geomorphologies along its basins (S.O.S. Amazônia 1998), it is possible to find the three types of water (white, clear and black).

In this study we attempt to answer whether there is correspondence between macroinvertebrate communities and the typological classification of white and clear-water streams in western Amazonian lowlands, particularly in the northern area of the Serra do Divisor National Park (SDNP), one of the most pristine and understudied areas of the western Brazilian Amazonia. Considering that watercolor types could serve as good 'surrogates' of more complex variables in nature (e.g. vegetation patterns, water chemistry, nutrient content, potential productivity and biological interactions), we predict significant differences in terms of composition and abundance in macroinvertebrate communities between stream types. In addition, regarding the increasing demand for methods of rapid stream bioassessment in tropical region, including taxonomic resolution simplification, we assess how concordant is the pattern of macroinvertebrate variation between stream types based on genus/ morphospecies and family level identification. We also discuss the implications of our findings for future biomonitoring programs in the region.

\section{Materials and Methods}

\section{Study area}

The north area of the Serra do Divisor National Park (SDNP) is located in the Acre State, the most western Brazilian Amazonia extremity (Figure $17^{\circ} 09^{\prime} 55^{\prime} \mathrm{S}$ and $73^{\circ} 43^{\prime} 55^{\prime} \mathrm{W}$ ). The altitude in the region varies from $200 \mathrm{~m}$ to $650 \mathrm{~m}$ and the annual rainfall is around 2,200 $\mathrm{mm}$ (S.O.S. Amazônia 1998). The mean annual temperature is $26^{\circ} \mathrm{C}$ along the rainy season, possibly reaching $4{ }^{\circ} \mathrm{C}$ in the drier months. The SDNP includes a diversity of geological formations within its limits as a result of the complex evolutionary history associated with the geological processes that occurred in the Amazonian region. The study area consists of a series of elevations and valleys, and it is covered by primary and secondary Open Tropical Forest.

We worked within two distinct hydrographic basins of the SDNP (Figure 1): River Moa catchment (clear-water streams) and River Azul catchment (white-water streams). We used a comprehensive classification of white and clear stream waters based on a visual evaluation of the color of the water. We sampled 10 streams in each basin, varying from first to second orders. These streams were fairly typical of forested headwater streams in Amazonian dry land with water depths less than $50 \mathrm{~cm}$, canopy covered $\sim 70 \%$ of the channel, absence of macrophytes and high dissolved oxygen levels. Streams were slightly acidic for clear water ( $\mathrm{pH} 5.12$ to 6.46) and white water (pH 5.85 to 6.92). Water temperature ranged from $23.8-24.8^{\circ} \mathrm{C}$ in clear water and from $23.2-24.5^{\circ} \mathrm{C}$ in white water. The substrates of the clear-water streams were characterized by a predominance of rocks and sand whereas white-water streams had an abundance of organic matter and mud. Electric conductivity ranged from 1 to $10 \mathrm{mS} / \mathrm{cm}^{-1}$ (in clear waters), and from 10 to $80 \mathrm{mS} / \mathrm{cm}^{-1}$ (in white waters).

\section{Sampling design}

We adopted a stratified sampling design to investigate macroinvertebrate distribution in pools and riffle habitats, with three samples in each one. We collected macroinvertebrates on a single occasion with a Surber sampler to a depth of $\sim 5 \mathrm{~cm}$ within the substrate of each stream. Afterwards all subsamples were pooled for statistical analyses.

Specimens were identified to the lowest practical level possible, due to limited knowledge of Neotropical fauna. Specimens were preserved in alcohol $70 \%$ and were deposited in the collection of the Universidade Federal do Acre.

\section{Statistical analysis}

We checked the magnitude of the difference among the two water types in relation to taxa abundance using a t-test. We used Non-metric Multidimensional Scaling (NMDS) to generate a two-dimensional ordination as a visual summary of the associations between streams. The taxa abundance matrix was logged $[\operatorname{logbase}(x+1)]$ to calculate an association matrix (Bray-Curtis dissimilarity). A stress level, or measure of the goodness of fit, was calculated for each ordination. Lower stress values are desirable, as indicated by values of 0.2 or less (Clarke \& Warwick 2005). The result matrix of Bray-Curtis was submitted to a one-factor ANOSIM (Analysis of Similarity).

We evaluated the relative contributions of different taxa to dissimilarities using a Similarity Percentage Analysis (SIMPER) routine (Clarke 1993). We calculated the degree of concordance between different taxonomic resolutions using the second-stage NMDS procedure (Somerfield \& Clarke 1995). This analysis generate a 'second stage' similarity matrix based on the Spearman rank 


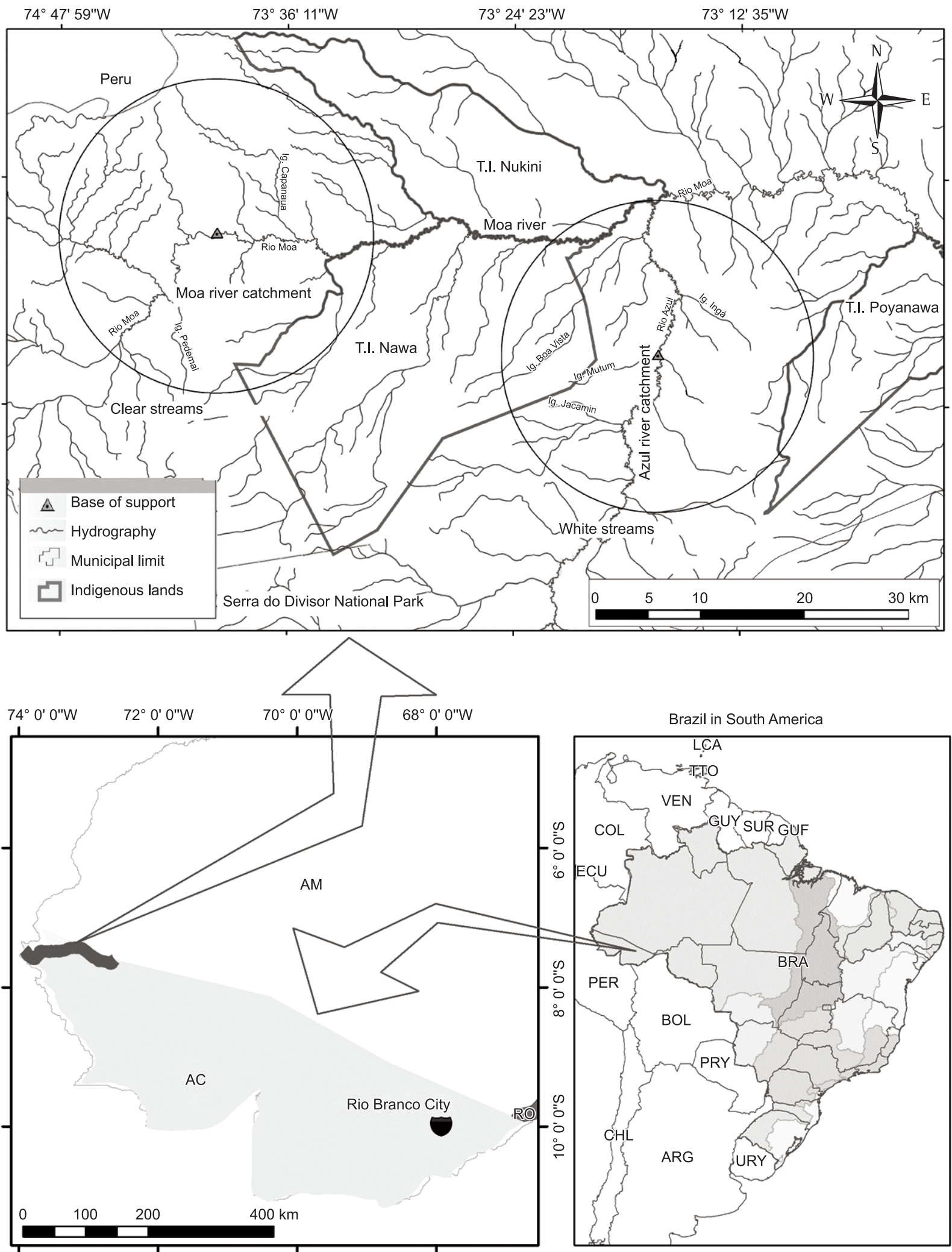

Figure 1. The sampling areas in Parque Nacional da Serra do Divisor, Acre, Brazil: Moa river catchment characterized by clear waters (left circle) and Azul river catchment characterized by white waters (right circle).

correlation $(\mathrm{q})$ between the similarity matrices resulting from the data sets; when $q=0$, there is no concordance between matrices and when $\mathrm{q}=1$, the different data sets are identical. The significance of q was determined using a permutation test (Clarke \& Gorley 2001).

\section{Results}

We collected a total of 2,952 individuals, distributed in 134 taxa, which belong to 65 families and 13 orders. We found that the total 
number of individuals was significantly higher $(\mathrm{t}=-4.10 ; p<0.001)$ in clear-water streams $(1,972)$ than in white-water streams $(980)$.

The abundance of Decapoda $(\mathrm{t}=3.99 ; p<0.001)$, Ephemeroptera $(\mathrm{t}=2.64 ; p=0.016)$ and Hemiptera $(\mathrm{t}=2.83 ; p=0.01)$, was significantly higher in white waters than in clear waters. In clear-water streams Diptera $(\mathrm{t}=-5.55 ; p<0.001)$, Plecoptera $(\mathrm{t}=-1.80 ; p=0.08)$ and Trichoptera $(\mathrm{t}=-9.85 ; p<0.001)$ were significantly more abundant. In the case of Hirudinea $(\mathrm{t}=1.03 ; p=0.31)$, Megaloptera $(\mathrm{t}=-0.70 ; p=0.48)$, and Odonata $(\mathrm{t}=0.11 ; p=0.90)$, no significant differences between stream types were found.

\section{Comparing taxonomic patterns in white water and clear water streams at family level}

The NMDS ordination indicated a clear separation in the community organization between clear waters and white waters when using family level identification (Stress $=0.202$; Figure 2). We found that macroinvertebrate community structure was significantly different between stream types (ANOSIN; $R=0.9993 ; p<0.001$ ) and that Leptophlebiidae $(20.21 \%)$, Trichodactylidae $(13.96 \%)$, Corixidae $(13.56 \%)$, and Gomphidae $(12.41 \%)$ were the most important groups characterizing white-water streams, whereas clear waters were characterized by Hydropsychidae (10.30\%), Gomphidae (7.89\%), Tanypodinae (7.70\%), and Chironominae (7.48\%) (SIMPER analysis). Hydropsychidae (5.48\%), Odontoceridae (4.43\%), Elmidae $(4.36 \%)$, Ptilodactilidae $(4.36 \%)$, Corixidae $(3.76 \%)$, Tanypodinae $(3.52 \%)$, Orthocladiinae $(3.39 \%)$, and Trichodactylidae $(3.35 \%)$, were important in determining differences between the water types.

\section{Comparing taxonomic patterns in white-water and clear-water streams at genus level}

Of the 134 genera identified in the two water types, 44 exclusively occurred in clear waters and 24 in the white ones. Among the genera we found in white waters, Tipulidae 1 occurred in all streams whereas Trichodactylidae 1 and Miroculis (Leptophlebiidae) were present in all samples of the clear-water streams.

We also found a clear separation of the macroinvertebrate communities between clear and white waters based on genus level identification (NMDS analysis; Stress = 0.144; Figure 3). Community organization was also significantly different between water types (ANOSIM; $R=0.9995 ; p<0.001$ ).

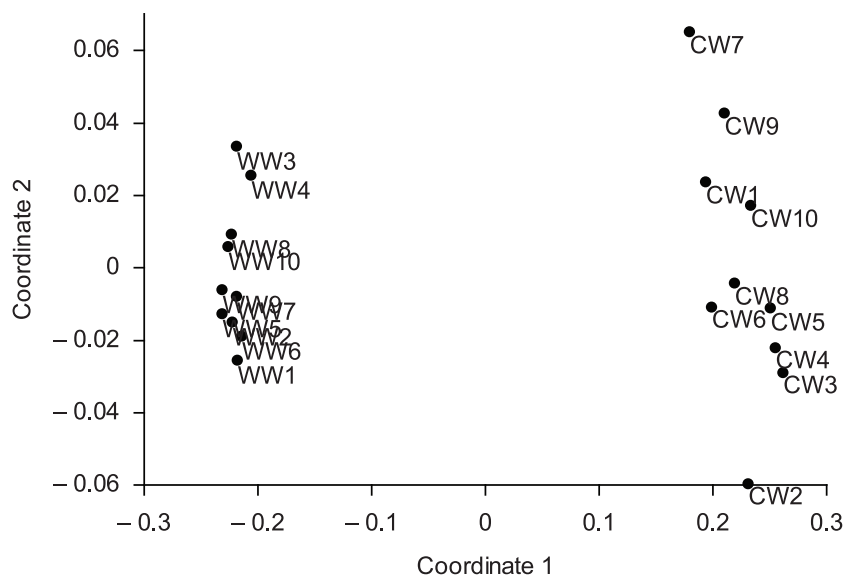

Figure 2. NMDS ordination (Bray-Curtis) of macroinvertebrate structure communities at family level in streams in Serra do Divisor National Park, Acre, Brazil. Stress $=0.2021$ ( $\mathrm{cw}=$ clear water; $\mathrm{ww}=$ white water $)$.
Assemblages in white-water streams were typified by Miroculis (18.59\%), Trichodactylidae 1 (13.96\%), Corixidae $1(13.58 \%)$, Brasilocaenis (6.71\%), and Farrodes (4.39\%), whereas Smicridea (9.46\%), Miroculis $(5.88 \%)$, Marilia (5.08\%), Ptilodactilidae 1 (4.89\%), Anacroneuria (4.59\%), Progomphus (4.56\%), and Neoelmis $(4.56 \%)$ were the most important in typifying clear-water streams.

Seventy-one genera accounted for $90 \%$ of the dissimilarities between groups. Smicridea (3.64\%), Trichodactilidae 1 (3.35\%), Marilia (2.98\%), Ptilodactilidae 1 (2.95\%), Neoelmis (2.86\%), Corixidae 1 (2.59\%), Anacroneuria (2.24\%), and Brasilocaenis $(2.16 \%)$ were the most important taxa (Appendix 1).

The second-stage NMDS analysis showed that the arrangement of the rank order of similarities in the matrix derived from the family and genus level was correlated $(q=0.80)$. This means that there is little difference between analyses based on genus and family level.

\section{Discussion}

\section{Macroinvertebrate commnunity patterns}

Black, white and clear water Amazonian streams are expected to have different biotic communities (Fittkau 1971), but these patterns have been documented quantitatively only recently. Most studies have documented patterns of macroinvertebrate communities between black and white streams which correspond to the Solimões and Negro River catchments. Walker (1995) compared macroinvertebrate communities from both water types (black and white) and showed that the taxonomic composition seems to be similar, but taxa richness and abundance seems to be greater in black-water streams. Here we show that there is a correspondence between previously established classifications (clear and white-water streams) and macroinvertebrate communities, at both genus and family resolutions.

The most abundant and frequent taxa collected in this study were Decapoda, Ephemeroptera, Odonata and Chironomidae. These groups have also been showed to be the most frequent taxa in Central Amazonian black water streams (Walker 1995) and in less impacted streams around Manaus (Couceiro et al. 2007).

The significant differences we found between clear and white water streams, based on many typifying taxa, suggest that the biological processes that act to influence taxa establishment and their persistence is manifested most strongly at this regional spatial scale with different groups behaving in a dominant way depending

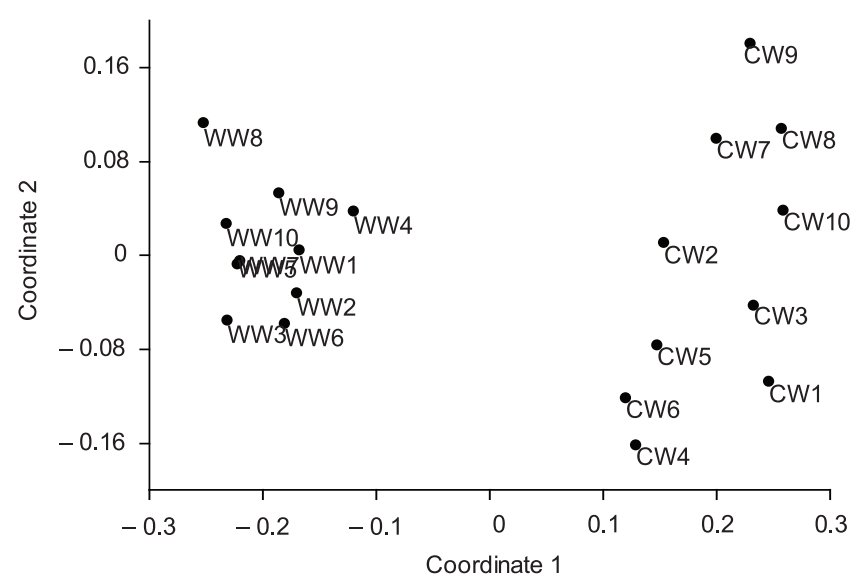

Figure 3. NMDS ordination (Bray-Curtis) of macroinvertebrate structure communities at genus level in streams in Serra do Divisor National Park, Acre, Brazil. Stress $=0.1441(\mathrm{cw}=$ clear water; $\mathrm{ww}=$ white water $)$. 
on the stream type. It is particularly important to the understanding of Amazonian biogeographical patterns that we can distinguish between historical and contemporaneous processes affecting stream biodiversity (Tuomisto \& Ruokolainen 1997). As no physical barrier seems to separate our sampling areas of white and clear waters, at least for adults of aquatic insects, we believe that the patterns evidenced in our analysis are most related to local contemporaneous ecological filters acting regionally in the same species pool.

There are few similar studies that can be quantitatively compared to our results. Grossly comparing our findings with those from streams of central Amazonia, macroinvertebrate richness at genus level found in the present study is similar to the 152 taxa found in 68 streams studied by Couceiro et al. (2007) and the 151 taxa in 20 streams reported by Nessimian et al. (2008). Unfortunately, few data are available from low-order streams of other Neotropical forested biomes for macroinvertebrate communities at the regional scale, so direct comparisons are difficult because the methods and taxonomic resolution differed considerably. Studies on macroinvertebrate diversity in Atlantic forest streams of South-eastern Brazil found taxa richness ranging from 117-162 (Melo \& Froehlich 2001, Baptista et al. 2001) which provides evidence to support the proposition of Vinson \& Hawkins (2003) that streams within similar biomes have similar numbers of aquatic insects regardless of the biogeographical area. However, taking a more detailed taxonomic resolution, it is clear that species richness is underestimated due to low taxonomic resolution. For example, Roque et al. (2007) assessed chironomid species richness only from 15 low-order streams in the Atlantic rainforest and distinguished a total of 191 morphospecies, and estimated a species richness ranging from 200 (credibility interval, 195-207) to 267 (248-288).

There are some non-exclusive reasons to explain why macroinvertebrate communities correspond to water types. First, our findings agree with previous studies that found associations between the distribution patterns of aquatic insects and the geographical features through which streams flow, especially where marked differences in topography or water chemistry (e.g. conductivity and $\mathrm{pH}$ ) are found (Hawkins \& Norris 2000, Roque et al. 2010, Siqueira et al. 2012). Second, Amazonian stream classification based on color may reflect fundamental discontinuities of nature (e.g. vegetation patterns, substrate composition, water chemistry, nutrient content, potential productivity and biological interactions), which could serve as a good 'surrogate' for relevant indicators of benthic organism diversity. Third, biological interactions can play an important role in shaping the distributional patterns of aquatic insects in Amazonian streams. In nutrient-poor waters, fungi play the most important role at the beginning of decomposition process of litter, while in white waters bacteria dominate. As white and clear water streams are characterized by differences in the amount of macroconsumers and habitat quality, there is likely to be a trade-off between strategies to avoid predation and strategies to live in waters with high amounts of sediment, which may influence macroinvertebrate distributions in clear and white water streams. Fourth, the importance of considering ecological variation related to geographical location has been stressed in recent years (Legendre 1993, Roque et al. 2010). The spatial structure of ecological communities can be molded by abiotic and biotic process (e.g. population growth, geographic organization, differential fertility or mortality, social organization, competition). In our study, the spatial location of streams sampled may account for a significant portion of the variation in macroinvertebrate distributional data. Such patterns detected at genus level are most likely to be related to the non-random distribution of the streams sampled (e.g. the clear streams were close to each other, the same for clear waters). The spatial distribution of the streams may also underlie relevant biological factors not measured here (e.g. biological interactions). Considering the fact that watertype distributions are not randomly distributed across the Amazonian landscape, we emphasize the need to consider geographical location when interpreting biodiversity distributions at the regional scale (Heino et al. 2003, Roque et al. 2010).

\section{Biomonitoring implication}

Freshwater monitoring strategies rely on stream classifications based on environmental and biotic groups and this approach is the cornerstone of most biomonitoring programs. Classification is therefore a critical component in many bioassessment programs designed to assess the health of streams, small rivers, lakes, and some estuaries (Bailey et al. 1998). Inferences are typically derived from a classification of sites that relates variation in biological proprieties of interest to class memberships. It is imperative that the most robust classification systems possibly are developed and implemented. Our analyses show that macroinvertebrate communities, at genus as well as family level, are concordant to a priori classifications that distinguish between white and clear water streams. The main implication of our results for biomonitoring is that biotic variation between white and clear streams can be partitioned regionally, which would improve the bioassessment accuracy of the Amazonian streams.

The taxonomic resolution used in our analysis has practical consequences for water biomonitoring. In our study, family and genus levels yielded the same pattern differentiating white and clear Amazonian streams. These results agree with previous studies suggesting that family-level information is enough for grossly detecting ecological patterns (Marchant et al. 1995, Melo 2005, Feio et al. 2006). However we are only beginning to document macroinvertebrates in white and clear streams in Amazonia. Information from other parts of Amazonia is essential for understanding macroinvertebrate distributional patterns and for testing the generality of the results detected here.

From an applied perspective, knowledge about macroinvertebrate occurrences in preserved and impacted Amazonian streams is fundamental for future biomonitoring programs. For instance, white water streams contained predominantly Chironomidae, which are often associated with impacted areas and/or areas with low water flow, whereas clear water streams were characterized by great numbers of EPT and by the presence of sensitive taxa (e.g. Polythoridae), groups associated with areas of low anthropic influence and higher water flow. This means that one type of stream can not be used as reference for the other. For example, if one use clear water stream biological information for setting expectations about the ecological condition of white water streams, we can run the risk of interpreting white water streams as 'naturally impacted'. Therefore, future biomonitoring programs in Amazonian streams should be based on regional information about its biodiversity; in contrast, we could misinterpret ecological conditions of Amazonian streams.

\section{Acknowledgements}

We thank Conselho Nacional de Desenvolvimento Científico e Tecnológico (CNPq) (Edital MCT/CNPq/CT-Hidro-No 039/2006) and Instituto do Meio Ambiente (IBAMA, Cruzeiro do Sul, Acre, Brazil) for financial and logistic support, respectively. R. Mariano (Ephemeroptera), L. Onofre (Odonata), A. Calor (Trichoptera), L. Lecci (Plecoptera), provided taxonomic identifications. We also thank A.M. de Oliveira, S.R.M. Couceiro and V.L. Landeiro for comments that greatly improved the content and clarity of this manuscript, and L. Menezes and J. Maria for guidance in the field. D.V.M. Lima received a CAPES scholarship. S. Trivinho-Strixino and F. O Roque are CNPq research fellows. 


\section{References}

BAPTISTA, D.F., DORVILLÉ, L.F.M., BUSS, D.F. \& NESSIMIAN, J.L. 2001. Spatial and temporal organization of aquatic insect assemblages in the longitudinal gradient of a tropical river. Braz. J. Biol. 61:295-304.

BAILEY, R.C., KENNEDY, M.G., DERVISH, M.Z. \& TAYLOR, A.R.M. 1998. Biological assessment of freshwater ecosystems using a reference condition approach: comparing predicted and actual benthic invertebrate communities in Yukon streams. Freshwater Biol. 39:765-774.

CLARKE, K.R. 1993. Non-parametric multivariate analyses of changes in community structure. Aust. J. Ecol. 18:117-143. http://dx.doi. org/10.1111/j.1442-9993.1993.tb00438.x

CLARKE, K.R. \& GORLEY, R.N. 2001. Software PRIMER. Primer-E Ltd., Plymouth, v.5.

CLARKE, K.R. \& WARWICK, R.M. 2005. Change in marine communities - an approach to statistical analysis and interpretation. 2. ed. Plymouth, Primer-E Ltd.

COUCEIRO, S.R.M., HAMADA, N., LUZ, S.L.B., FORSBERG, B.R. \& PIMENTEL, T.P. 2007. Deforestation and sewage effects on aquatic macroinvertebrates in urban streams in Manaus, Amazonas, Brazil. Hydrobiologia 575:271-284.

FEIO, M.J., REYNOLDSON, T.B. \& GRAÇA, M.A.S. 2006. The influence of taxonomic level on the performance of a predictive model for water quality assessment. Can. J. Fish Aqua. Sci. 63:367-376.

FITTKAU, E.J. 1971. Distribution and ecology of Amazonian chironomids (Diptera). Can. Entomol. 103:407-413. http://dx.doi.org/10.4039/ Ent103407-3

GENTRY, A.H. 1988. Changes in plant community diversity and floristic composition on environmental and geographical gradients. Ann. Missouri Bot. Gard. 75:1-34. http://dx.doi.org/10.2307/2399464

HAWKINS, C.P \& NORRIS, R.H. 2000. Landscape classifications: aquatic biota and bioassessments. J. N. Am. Benthol. Soc. 19(3). http://dx.doi. org/10.2307/1468113

HEINO, J., MUOTKA, T., MYKRÄ, H., PAAVOLA, R., HÄMÄLÄINEN, H. \& KOSKENNIEMI, E. 2003. Defining macroinvertebrate assemblage type of headwater streams: implications for bioassessment and conservation. Ecol. Appl. 13:842-852.

JUNK, W.J. \& FURCH, K. 1985. Key Environments Amazonia. In The physical and chemical properties of the Amazonian waters and their relationships with the biota (GT Prance \& TE Lovejoy, eds.). Pergamon Press, Oxford, p.3-17.

JUNK, W.J. \& SOARES, M.G.M. 2001. Freshwater fish habitats in Amazonian: state of knowledge, management, and protection. AEHM 4:437-451.

LEGENDRE, P. 1993. Spatial autocorrelation: trouble or new paradigm? Ecology 74:1659-1673. http://dx.doi.org/10.2307/1939924

MARCHANT, R., BARMUTA, L.A. \& CHESSMAN, B.C. 1995. Influence of sample quantification and taxonomic resolution on the ordination of macroinvertebrate communities from running waters in Victoria, Australia. Mar. Fresh Res. 46:501-506.

MELO, A.S. \& FROEHLICH, C.G. 2001. Macroinvertebrates in neotropical streams: richness patterns along a catchments and assemblage structure between 2 seasons. J. N. Am. Benthol. Soc. 20:1-16.
MELO, A.S. 2005. Effects of taxonomic and numeric resolution on the ability to detect ecological patterns at a local scale using stream macroinvertebrates. Arch. Hydrobiol. 164:309-323. http://dx.doi. org/10.1127/0003-9136/2005/0164-0309

NESSIMIAN, J.L., VENTICINQUE, E.M., ZUANON, J., DE MARCO JUNIOR, P., GORDO, M., FIDELIS, L., BATISTA, J.D. \& JUEN, L. 2008. Land use, habitat integrity and aquatic insect ssemblages in Central Aamazonian streams. Hydrobiologia 614:117-131.

PADIAL, A.A., SIQUEIRA, T., HEINO, J., VIEIRA, L.C.G., BONECKER, C.C., LANSAC-TÔHA, F.A., RODRIGUES, L.C., TAKEDA, A.M., TRAIN, S., VELHO, L.F.M. \& BINI, L.M. 2012. Relationships between multiple biological groups and classification schemes in a Neotropical floodplain. Ecol. Indic. 13:55-65. http://dx.doi.org/10.1016/j. ecolind.2011.05.007

RÄSÄNEN, M., SALO, J.S. \& KALLIOLA, R.J. 1987. Long-term fluvial perturbance in the western Amazon basin: regulation by long-term subAndean tectonics. Science. 238:1398-1401.

ROQUE, F.O., SIQUEIRA, T., BINI, L.M., RIBEIRO, M.C., TAMBOSI, L.R., CIOCHETI, G. \& TRIVINHO-STRIXINO, S. 2010. Untangling associations between chironomid taxa in Neotropical streams using local and landscape filters. Freshwater Biol. 55:847-865. http://dx.doi. org/10.1111/j.1365-2427.2009.02314.x

ROQUE, F.O., TRIVINHO-STRIXINO, S., MILAN, L.A. \& LEITE, J.G. 2007. Chironomid species richness in low order streams in Brazilian Atlantic Forest: a first approximation through Bayesian approach. J. N. Am. Benthol. Soc. 26:221-231.

SIQUEIRA, T., BINI, L.M., ROQUE, F.O., COUCEIRO, S.R.M., TRIVINHO-STRIXINO, S. \& COTTENIE, K. 2012. Common and rare species respond to similar niche processes in macroinvertebrate metacommunities. Ecography 35:183-192. http://dx.doi.org/10.1111/ j.1600-0587.2011.06875.x

SIOLI, H. 1950. Das Wasser im Amazonasgebiet. Forsch. Fortschr. 26:274-280.

SIOLI, H. 1984. Amazon: limnology and landscape ecology of a mighty tropical river and its basin. In The Amazon and its main afluents: Hydrology, morphology of the river courses and river types (H. Sioli, ed.). Dordrecht, W. Junk Publishers, p.127-165.

SOMERFIELD, P.J. \& CLARKE, K.R. 1995. Taxonomic levels, in marine community studies, revisited. Mar. Ecol. Prog. Ser. 127:113-119.

S.O.S. AMAZÔNIA. 1998. Plano de Manejo do Parque Nacional da Serra do Divisor - PNSD. SOS Amazônia, IBAMA.

TUOMISTO, H. \& RUOKOLAINEN, K. 1997. The role of ecological knowledge in explaining biogeography and biodiversity in Amazonia. Biodiv. Conserv. 6:347-357.

VINSON, M.R. \& HAWKINS, C.P. 2003. Broad-scale geographical patterns in local stream insect genera richness. Ecography 26:751-767.

WALKER, I. 1995. Limnology in Brazil. In Amazonian streams and small rivers (J.G. Tundise, C.E. Bicudo \& T. Matsumura-Tundisi, eds.). ABC/ SBL, Rio de Janeiro, p.75-92.

WILSON, D.E. \& SANDOVAL, A. 1996. Manu-the Biodiversity of Southeastern Peru. Smithsonian Institution and Editorial Horizonte, Lima. 


\section{Appendix}

Appendix 1. Summary of SIMPER analysis identifying the contribution of individual taxa to total dissimilarity between water types in Amazonian streams, Acre, Brazil.

\begin{tabular}{|c|c|c|c|c|}
\hline Taxa & Genus & White water \% & Clear water \% & White vs Clear water \% \\
\hline \multicolumn{5}{|l|}{ Plecoptera } \\
\hline \multirow[t]{3}{*}{ Perlidae } & & 3.75 & 5.16 & 3.21 \\
\hline & Anacroneuria Klapálek & 2.17 & 4.59 & 2.24 \\
\hline & Macrogynoplax Lenderlein & - & 1.09 & 1.16 \\
\hline \multicolumn{5}{|l|}{ Trichoptera } \\
\hline \multirow[t]{2}{*}{ Calamoceratidae } & & - & 2.55 & 2.75 \\
\hline & Phylloicus Müller & - & 2.55 & 1.83 \\
\hline \multirow[t]{2}{*}{ Glossosomatidae } & & - & - & - \\
\hline & Glossomatidae 1 & - & - & - \\
\hline \multirow[t]{2}{*}{ Helicopsychidae } & & - & 3.40 & 2.44 \\
\hline & Helicopsyche Siebold & - & 3.57 & 1.66 \\
\hline \multirow[t]{6}{*}{ Hydropsychidae } & & - & 10.30 & 5.48 \\
\hline & Leptonema Guérin & - & 1.08 & 1.39 \\
\hline & Smicridea McLachlan & - & 9.46 & 3.64 \\
\hline & Synoestropsis Ulmer & - & - & 0.54 \\
\hline & Macronema Pictet & - & - & - \\
\hline & Macrostemum Kolenati & - & 1.76 & 1.28 \\
\hline \multirow[t]{4}{*}{ Leptoceridae } & & - & 2.81 & 2.77 \\
\hline & Nectopsyche Müller & - & - & 0.63 \\
\hline & Triplectides Kolenati & - & - & - \\
\hline & Oecetis McLachlan & - & 2.27 & 1.47 \\
\hline \multirow[t]{2}{*}{ Odontoceridae } & & - & 4.95 & 4.43 \\
\hline & Marilia Müller & - & 5.08 & 2.98 \\
\hline \multirow[t]{3}{*}{ Philopotamidae } & & - & - & 1.24 \\
\hline & Wormaldia McLachlan & - & - & 0.64 \\
\hline & Chimarra Stephens & - & - & 0.45 \\
\hline \multirow[t]{4}{*}{ Polycentropodidae } & & - & - & 1.33 \\
\hline & Polycentropodidae 1 & - & - & 0.44 \\
\hline & Polypectropus Ulmer & - & - & - \\
\hline & Cyrnellus Banks & - & - & - \\
\hline \multirow[t]{2}{*}{ Seracostomatidae } & & - & - & - \\
\hline & Seracostomatidae 1 & - & - & - \\
\hline \multirow[t]{2}{*}{ Xiphocentronidae } & & - & - & 1.40 \\
\hline & Xiphocentron Brauer & - & - & 0.99 \\
\hline \multicolumn{5}{|l|}{ Coleoptera } \\
\hline \multirow[t]{2}{*}{ Eylaidae } & & - & - & - \\
\hline & Eylaidae 1 & - & - & - \\
\hline \multirow[t]{2}{*}{ Crysomelidae } & & - & - & - \\
\hline & Crysomelidae 1 & - & - & - \\
\hline \multirow[t]{2}{*}{ Curculionidae } & & - & - & - \\
\hline & Curculionidae 1 & - & - & - \\
\hline \multirow[t]{2}{*}{ Dytiscidae } & & - & - & - \\
\hline & Dytiscidae 1 & & - & - \\
\hline \multirow[t]{3}{*}{ Elmidae } & & - & 4.72 & 4.36 \\
\hline & Neoelmis Musgrave & - & 4.56 & 2.86 \\
\hline & Heterelmis Sharp & - & - & - \\
\hline \multirow[t]{4}{*}{ Scirtidae } & & - & & 0.95 \\
\hline & Prionocyphon Redtenbacher & - & - & - \\
\hline & Scirtidae 1 & - & - & - \\
\hline & Cyphon Paykull & - & - & 0.65 \\
\hline
\end{tabular}


Appendix 1. Continued...

\begin{tabular}{|c|c|c|c|c|}
\hline Taxa & Genus & White water \% & Clear water \% & White vs Clear water \% \\
\hline \multirow[t]{2}{*}{ Haliplidae } & & 1.84 & - & 1.03 \\
\hline & Haliplidae 1 & 1.97 & - & - \\
\hline \multirow[t]{2}{*}{ Hydrophilidae } & & - & - & - \\
\hline & Tropisternus Solier & - & - & 0.35 \\
\hline \multirow[t]{2}{*}{ Noteridae } & & 1.67 & - & - \\
\hline & Noteridae 1 & 1.72 & 0.90 & - \\
\hline \multirow{2}{*}{ Ptilodactylidae } & & - & 4.72 & 4.36 \\
\hline & Ptilodactylidae 1 & - & 4.89 & 2.95 \\
\hline \multicolumn{5}{|l|}{ Diptera } \\
\hline \multirow[t]{2}{*}{ Ceratopogonidae } & & - & 3.80 & 2.75 \\
\hline & Ceratopogonidae 1 & - & 4.01 & 1.89 \\
\hline \multirow[t]{9}{*}{ Tanypodinae } & & 2.47 & 7.70 & 3.52 \\
\hline & Ablabesmyia Johannsen & - & 3.72 & 1.87 \\
\hline & Aff. Denopelopia Roback \& Rutter & - & - & - \\
\hline & Larsia Fittkau & - & - & 0.38 \\
\hline & Pentaneura Philippi & - & - & 0.54 \\
\hline & Zavrelimyia Fittkau & - & - & 0.38 \\
\hline & Coelotanypus Kieffer & - & - & 0.54 \\
\hline & DjalmabatistaFittkau & - & - & 0.37 \\
\hline & Procladius Skuse & - & - & 0.36 \\
\hline \multirow[t]{5}{*}{ Orthocladiinae } & & 4.90 & 7.72 & 3.39 \\
\hline & Corynoneura Winnertz & - & - & - \\
\hline & Thienemanniella Kieffer & - & - & 0.53 \\
\hline & Parametriocnemus Goetghebuer & - & 0.80 & 1.07 \\
\hline & Cricotopus v. d. Wulp & - & - & 0.40 \\
\hline \multirow[t]{19}{*}{ Chironominae } & & 6.03 & 7.48 & 3.05 \\
\hline & Beardius Reiss \& Sublette & - & - & 0.78 \\
\hline & Chironomus Meigen & - & - & 0.39 \\
\hline & Endotribelos Grodhaus & 1.76 & 2.34 & 1.43 \\
\hline & Fissimentum Cranston \& Nolte & - & - & - \\
\hline & Goeldichironomus Fittkau & - & - & 0.81 \\
\hline & Pelomus Reiss & - & - & - \\
\hline & Lauterborniella Thienemann \& Bause & - & - & - \\
\hline & Oukuriella Epler & - & - & - \\
\hline & Nilothauma Kieffer & - & - & - \\
\hline & Paratendipes Kieffer & - & - & 0.41 \\
\hline & Polypedilum Kieffer & 1.67 & 2.66 & 1.33 \\
\hline & Harnischia complex & - & - & - \\
\hline & Stenochironomus Kieffer & 0.94 & 0.86 & 1.14 \\
\hline & Caladomyia Säwedall & - & - & 1.03 \\
\hline & Tanytarsini sp1 & - & 1.14 & 1.12 \\
\hline & Rheotanytarsus Thienemann \& Bause & 2.58 & 2.36 & 1.63 \\
\hline & Tanytarsini & - & 1.93 & 1.37 \\
\hline & Tanytarsus v. d. Wulp & - & 2.34 & 1.48 \\
\hline \multirow[t]{2}{*}{ Diptera Family 1} & & - & - & - \\
\hline & Diptera 1 & - & - & - \\
\hline \multirow[t]{2}{*}{ Diptera Family 2} & & - & - & - \\
\hline & Diptera 1 & - & - & - \\
\hline \multirow[t]{2}{*}{ Culicidae } & & - & - & 1.99 \\
\hline & Culicidae 1 & - & 1.86 & 1.42 \\
\hline \multirow[t]{2}{*}{ Dixidae } & & - & - & - \\
\hline & Dixidae 1 & - & - & - \\
\hline
\end{tabular}


Appendix 1. Continued...

\begin{tabular}{|c|c|c|c|c|}
\hline Taxa & Genus & White water \% & Clear water \% & White vs Clear water \% \\
\hline \multirow[t]{2}{*}{ Dolichopodidae } & & - & - & - \\
\hline & Dolichopodidae 1 & - & - & - \\
\hline \multirow[t]{2}{*}{ Ephydridae } & & - & - & 0.70 \\
\hline & Ephydridae 1 & - & - & - \\
\hline \multirow[t]{2}{*}{ Muscidae } & & - & - & - \\
\hline & Muscidae 1 & - & - & - \\
\hline \multirow[t]{2}{*}{ Sciomyzidae } & & - & - & 0.82 \\
\hline & Sciomyzidae 1 & - & & 0.58 \\
\hline \multirow[t]{2}{*}{ Simuliidae } & & - & 1.87 & 2.72 \\
\hline & Simulium Latreille & - & 2.06 & 1.92 \\
\hline \multirow[t]{2}{*}{ Syrphidae } & & - & - & - \\
\hline & Syrphidae 1 & - & - & - \\
\hline \multirow{2}{*}{ Tabanidae } & & - & - & - \\
\hline & Tabanidae 1 & - & - & - \\
\hline \multirow[t]{2}{*}{ Tipulidae } & & - & 4.16 & 2.32 \\
\hline & Tipulidae 1 & - & - & 1.58 \\
\hline \multicolumn{5}{|l|}{ Ephemeroptera } \\
\hline \multirow[t]{3}{*}{ Baetidae } & & - & - & 1.41 \\
\hline & Americanbaetis Kluge & 1.12 & - & 0.88 \\
\hline & Zelusia Lugo-Ortz \& McCafferty & - & - & - \\
\hline \multirow[t]{2}{*}{ Caenidae } & & 6.27 & - & 3.12 \\
\hline & Brasilocaenis Puthz & 6.71 & - & 2.16 \\
\hline \multirow[t]{2}{*}{ Coloburiscidae } & & - & - & - \\
\hline & Coloburiscidae 1 & - & - & 0.45 \\
\hline \multirow[t]{3}{*}{ Leptohyphidae } & & - & - & - \\
\hline & Traverhyphes Molineri & - & - & 0.40 \\
\hline & Tricorythodes Ulmer & - & - & 0.56 \\
\hline \multirow[t]{10}{*}{ Leptophlebiidae } & & 20.21 & 6.71 & 2.88 \\
\hline & Farrodes Peters & 4.39 & - & 1.95 \\
\hline & Fittkaulus Hubbard & - & - & 0.66 \\
\hline & Microphlebia Savage \& Peters & - & - & - \\
\hline & Miroculis Edmundis & 18.59 & 5.88 & 1.86 \\
\hline & Perissophlebiodes Savage & - & - & 0.53 \\
\hline & Hagenulopsis Ulmer & - & - & 0.76 \\
\hline & Terdipes Demoulin & - & - & - \\
\hline & Thraulodes Ulmer & - & - & 0.93 \\
\hline & Ulmeritoides Traver & 1.69 & - & 0.98 \\
\hline \multirow[t]{2}{*}{ Polymitarcyidae } & & - & - & - \\
\hline & Polymitarcyidae 1 & - & - & - \\
\hline \multicolumn{5}{|l|}{ Hemiptera } \\
\hline \multirow[t]{2}{*}{ Belostomatidae } & & 2.06 & - & 1.58 \\
\hline & Belostomatidae 1 & 2.18 & - & 1.10 \\
\hline \multirow[t]{2}{*}{ Corixidae } & & 12.96 & 1.98 & 3.76 \\
\hline & Corixidae 1 & 13.58 & 2.09 & 2.59 \\
\hline \multirow[t]{2}{*}{ Gerridae } & & - & - & - \\
\hline & Gerridae 1 & - & - & - \\
\hline \multirow[t]{2}{*}{ Nepidae } & & - & - & - \\
\hline & Nepidae 1 & - & - & - \\
\hline Notonectidae & & - & - & 1.32 \\
\hline & Notonectidae 1 & - & - & 0.91 \\
\hline Veliidae & & - & - & - \\
\hline & Veliidae 1 & - & - & - \\
\hline Megaloptera & & & & \\
\hline
\end{tabular}


Appendix 1. Continued...

\begin{tabular}{|c|c|c|c|c|}
\hline Taxa & Genus & White water \% & Clear water \% & White vs Clear water \% \\
\hline \multirow[t]{3}{*}{ Corydalidae } & & - & - & - \\
\hline & Corydalus Latreille & - & - & - \\
\hline & Corydalidae 1 & - & - & - \\
\hline \multicolumn{5}{|l|}{ Odonata } \\
\hline \multirow[t]{2}{*}{ Aeshnidae } & & - & - & - \\
\hline & Gynacantha Rambur & - & - & 0.53 \\
\hline \multirow[t]{4}{*}{ Coenagrionidae } & & - & - & 1.01 \\
\hline & Argia Rambur & - & - & - \\
\hline & Cyanallagma Kennedy & - & - & - \\
\hline & Oxyagrion Selys & - & - & - \\
\hline \multirow[t]{2}{*}{ Dicteriadidae } & & - & - & - \\
\hline & Heliocharis Selys & - & - & - \\
\hline \multirow[t]{2}{*}{ Cordulidae } & & - & - & - \\
\hline & Cordulidae 1 & - & - & 0.42 \\
\hline \multirow[t]{9}{*}{ Gomphidae } & & 12.41 & 7.89 & 1.41 \\
\hline & Agriogomphus Selys & 5.76 & 0.96 & 1.67 \\
\hline & Aphylla Selys & - & - & 0.41 \\
\hline & Desmogomphus Selys & - & - & - \\
\hline & Gomphoides Selys & - & - & 0.90 \\
\hline & Neogomphus Selys & - & - & - \\
\hline & Peruviogomphus Klots & - & - & - \\
\hline & Phyllocycla Calvert & - & - & - \\
\hline & Progomphus Selys & 4.20 & 4.56 & 1.63 \\
\hline \multirow[t]{2}{*}{ Polythoridae } & & - & 2.77 & 2.19 \\
\hline & Chalcopteryx Selys & - & 2.90 & 1.50 \\
\hline \multirow[t]{2}{*}{ Perilestidae } & & 3.08 & - & 2.00 \\
\hline & Perilestes Selys & 3.27 & - & 1.38 \\
\hline \multirow[t]{4}{*}{ Protoneuridae } & & - & - & - \\
\hline & Epipleoneura William & - & - & - \\
\hline & Neoneura Selys & - & - & - \\
\hline & Protoneura Selys & - & - & - \\
\hline \multirow[t]{3}{*}{ Megapodagrionidae } & & - & - & 0.92 \\
\hline & Heteragrion Selys & - & - & 0.53 \\
\hline & Oxystigma Selys & - & - & - \\
\hline \multirow[t]{7}{*}{ Libellulidae } & & - & - & 2.00 \\
\hline & Brechmorhoga Kirby & - & - & 0.92 \\
\hline & Libellulidae 1 & - & - & - \\
\hline & Gynothemis Calvert & - & - & - \\
\hline & Macrothemis Hagen & - & - & - \\
\hline & Orthemis Hagen & - & - & - \\
\hline & Perithemis Hagen & - & - & 0.39 \\
\hline \multirow[t]{2}{*}{ Decapoda } & & 13.16 & - & - \\
\hline & Trichodactylidae 1 & 13.96 & - & 3.35 \\
\hline \multirow[t]{2}{*}{ Palaemonidae } & & - & - & 1.97 \\
\hline & Macrobranchium Bate & - & 1.66 & 1.38 \\
\hline \multirow[t]{2}{*}{ Nematoda } & & - & - & - \\
\hline & Nematoda 1 & - & - & - \\
\hline \multicolumn{5}{|l|}{ Annelida } \\
\hline \multirow[t]{2}{*}{ Hirudinea } & & - & - & 1.14 \\
\hline & Hirudinea 1 & 1.24 & - & 0.78 \\
\hline Oligochaeta & & - & - & - \\
\hline \multirow[t]{2}{*}{ Gastropoda } & & - & - & 1.33 \\
\hline & Pomacea (Perry) & 0.95 & - & - \\
\hline
\end{tabular}

